\title{
A marine bacterium, Micrococcus MCCB 104, antagonistic to vibrios in prawn larval rearing systems
}

\author{
N. S. Jayaprakash ${ }^{1,3}$, S. Somnath Pai ${ }^{1}$, A. Anas ${ }^{1}$, R. Preetha1, Rosamma Philip ${ }^{2}$, \\ I. S. Bright Singh ${ }^{1, *}$ \\ ${ }^{1}$ Centre for Fish Disease Diagnosis and Management, School of Environmental Studies, and ${ }^{2}$ Department of Marine Biology, \\ Microbiology and Biochemistry, School of Marine Sciences, Cochin University of Science and Technology, \\ Lake Side Campus, Fine Arts Avenue, Cochin 682016 Kerala, India \\ ${ }^{3}$ Present address: Centre for Bioseparation Technology, Vellore Institute of Technology, Vellore 632014 Tamil Nadu, India
}

\begin{abstract}
A marine bacterium, Micrococcus MCCB 104, isolated from hatchery water, demonstrated extracellular antagonistic properties against Vibrio alginolyticus, V. parahaemolyticus, V. vulnificus, V. fluviallis, V. nereis, V. proteolyticus, V. mediterranei, V. cholerae and Aeromonas sp., bacteria associated with Macrobrachium rosenbergii larval rearing systems. The isolate inhibited the growth of $V$. alginolyticus during co-culture. The antagonistic component of the extracellular product was heat-stable and insensitive to proteases, lipase, catalase and $\alpha$-amylase. Micrococcus MCCB 104 was demonstrated to be non-pathogenic to $M$. rosenbergii larvae.
\end{abstract}

KEY WORDS: Vibrio $\cdot$ Micrococcus $\cdot$ Antagonism $\cdot$ Macrobrachium $\cdot$ Probiotic

Resale or republication not permitted without written consent of the publisher

\section{INTRODUCTION}

Among heterotrophic bacteria associated with larviculture and grow-out phases of crustaceans, Vibrio is a dominant genus responsible for much of the observed mortality (New 1995, Sung et al. 1999). Vibriosis has been a major hindrance to prawn culture in India and in other prawn-farming countries (Baticados et al. 1990, Singh 1990, Lightner 1996). To control vibrios, prophylactic and therapeutic use of antibiotics has been the choice in commercial hatcheries; however, this has led to resistance and the possible spread of vibrios in the environment (Weston 1996, Hameed et al. 2003).

As an alternate management measure, the introduction of selected bacterial cultures/products as probiotics with antagonistic properties has been proposed and applied (Gomez-Gil et al. 2000). Many bacterial isolates, which are common members of the nonpathogenic microflora of fish and shellfish culture systems, have been shown to inhibit fish and prawn pathogens in vitro. This has been demonstrated for lactic acid bacteria (Gatesoupe 1994), Carnobacterium (Robertson et al. 2000), Bacillus (Rengpipat et al. 2000), Vibrio (Austin et al. 1995), Planococcus (Austin \& Billaud 1990) and Pseudomonas (Chythanya et al. 2002). Gomez-Gil (1995) and Verschuere et al. (2000) claimed that certain strains of bacteria associated with Artemia and prawn culture systems have the ability to control pathogens by means of competitive exclusion or by the production of inhibitory compounds. The antibacterial effect may be due to production of antibiotics (Williams \& Vickers 1986), bacteriocins (Vandenbergh 1993), hydrogen peroxide, or alteration of $\mathrm{pH}$ by producing organic acids (Sugita et al. 1997). In aquaculture, Micrococcus has been documented by Austin \& Allen (1982) and Prieto et al. (1987) in dehydrated Artemia salina cysts, cyst-hatching water and A. salina nauplii. Irianto \& Austin (2002a) investigated the probiotic effect of a Gram-positive cocci (A1-6) to control furunculosis in rainbow trout, which apparently was $M$. luteus (Irianto \& Austin, 2002b). Lalitha \& Surendran 
(2004) reported Micrococcus in the environment of the farmed freshwater prawn Macrobrachium rosenbergii. However, there is a paucity of information on the antagonistic properties of the genus.

In the present work we have investigated the antagonistic properties of Micrococcus MCCB 104, an isolate obtained from hatchery seawater, to Vibrio spp. associated with prawn larval rearing systems. The in vitro antagonistic property of the isolate was evaluated using a disc diffusion assay, as well as co-culture methods. The pathogenicity of Micrococcus MCCB 104 towards Macrobrachium rosenbergii larvae in a bioassay system was also evaluated in order to explore its potential use as a 'probiotic with antagonism' for controlling vibrios in prawn larviculture.

\section{MATERIALS AND METHODS}

Bacterial isolates and culture conditions. Three groups of microorganisms served as targets for screening the antagonistic properties of Micrococcus sp. in this study (Table 1). They were 55 isolates of Vibrio ( $V$. cholerae [12 isolates], V. mediterranei [7], V. vulnificus [8], V. nereis [11], V. parahaemolyticus [4], V. fluvialis
[1], V. proteolyticus [2], V. splendidus II [2] and V. alginolyticus [8]) from larval rearing systems of Macrobrachium rosenbergii and isolates of Bacillus sp., Pseudomonas sp. and Aeromonas sp., associated with prawn culture systems (obtained from the culture collection of Centre for Fish Disease Diagnosis and Management, Cochin University of Science and Technology, Kerala, India), 7 isolates of marine yeasts and 6 marine actinomycetes (obtained from Department of Marine Biology, Microbiology and Biochemistry, School of Marine Sciences, Cochin University of Science and Technology). The antagonistic Micrococcus MCCB 104 was isolated from seawater sampled from a prawn hatchery in Kerala and identified following the scheme of Buchanan \& Gibbons (1974). All isolates were grown either in ZoBell's 2216E agar or broth (HiMedia), prepared in 15 ppt seawater and incubated at $28^{\circ} \mathrm{C}$ unless otherwise indicated.

Antagonism assay. Antagonism of Micrococcus MCCB 104 towards the target microbial cultures was detected by the disc diffusion method; $6 \mathrm{~mm}$ diameter discs from Whatman No.1 filter papers (stack of 3 filter papers) were prepared, sterilised at $121^{\circ} \mathrm{C}$ for $15 \mathrm{~min}$ and dried. These discs were placed on ZoBell's marine agar plates, previously swabbed with the target bacte-

Table 1. Spectrum of inhibition of bacterial taxon by Micrococcus MCCB 104

\begin{tabular}{|c|c|c|}
\hline Bacterial taxon & Code & Source \\
\hline \multicolumn{3}{|c|}{ (A) Inhibited by Micrococcus MCCB 104} \\
\hline Vibrio cholerae & $\operatorname{MRCS} 11,12,13,16,17,19,20,21,23,35,37,39$ & Macrobrachium rosenbergii larvae \\
\hline Vibrio mediterranei & MRCS 15, 18, 22, 32, 34, 36; MRQL 27 & Macrobrachium rosenbergii larvae \\
\hline Vibrio vulnificus & MRQL 5, 9, 10, 19, 20, 23, 33, 36 & Macrobrachium rosenbergii larvae \\
\hline Vibrio nereis & MRCS 24, 28, 29, 30, 31, 33; MRQL 13, 29, 32, 34, 35 & Macrobrachium rosenbergii larvae \\
\hline Vibrio parahaemolyticus & $\operatorname{MRCS} 1,6,8,9$ & Macrobrachium rosenbergii larvae \\
\hline Vibrio fluviallis & MRCS 26 & Macrobrachium rosenbergii larvae \\
\hline Vibrio proteolyticus & $\operatorname{MRCS} 4,10$ & Macrobrachium rosenbergii larvae \\
\hline Vibrio alginolyticus & $\begin{array}{l}\text { MCCB } 112 \\
\text { MRNL 1, 2, 4, 5, 6, 7, } 8\end{array}$ & Diseased Macrobrachium rosenbergii larvae \\
\hline Aeromonas sp. & $\begin{array}{l}\text { MRCS } 2,7 \\
\text { MRNL } 9,10,16,17\end{array}$ & Macrobrachium rosenbergii larvae \\
\hline \multicolumn{3}{|c|}{ (B) Not inhibited by Micrococcus MCCB 104} \\
\hline Vibrio splendidus II & MRCS 3, 5 & Macrobrachium rosenbergii larvae \\
\hline Bacillus sp. & MCCB 101 & Prawn grow-out \\
\hline Pseudomonas sp. & PS-1, MCCB 103 & Brackish water lagoon, prawn grow-out \\
\hline Debaryomyces hansenii & S8, S87, S100, S169 & Seawater, southwest coast of India \\
\hline Candida sake & S165 & Seawater, southwest coast of India \\
\hline Candida tropicalis & S186 & Seawater, southwest coast of India \\
\hline Torulospora delbruecki & S303 & Seawater, southwest coast of India \\
\hline Streptomyces sp. & B272, B377 & Seawater, southwest coast of India \\
\hline Streptomyces fradiae & B451 & Seawater, southwest coast of India \\
\hline Streptomyces griseoflavus & B301 & Seawater, southwest coast of India \\
\hline Streptomyces pulveraceus & B361 & Seawater, southwest coast of India \\
\hline Streptomyces californicus & B30 & Seawater, southwest coast of India \\
\hline
\end{tabular}


rial isolates. Aliquots $(20 \mu \mathrm{l})$ of the Micrococcus MCCB 104 culture in ZoBell's marine broth (incubated for $5 \mathrm{~d}$ at $28^{\circ} \mathrm{C}$ ) were pipetted onto the discs. The plates were incubated for $24 \mathrm{~h}$ at $28^{\circ} \mathrm{C}$, and the formation of a zone of clearing around the discs was considered a positive indication of inhibitory activity.

Antagonism of cell-free culture supernatant. Micrococcus MCCB 104 was grown in ZoBell's broth for $5 \mathrm{~d}$ on a shaker (90 rpm) at room temperature (approx. $28^{\circ} \mathrm{C}$ ). The cells were pelleted by centrifugation $(10000 \times g, 10 \mathrm{~min})$, the $\mathrm{pH}$ of the supernatant adjusted to 7.0 and then passed through a $0.2 \mu \mathrm{m}$ pore-size cellulose-acetate membrane filter (Sartorius). Inhibitory activity on the target microbial cultures was detected by the disc diffusion method, as described above, and the zone of inhibition around the discs was recorded after $24 \mathrm{~h}$ using a HiAntibiotic ZoneScale (HiMedia).

Time course of growth and production of the antagonistic substance. Commencement of the antagonistic substance production, its peak activity and duration of sustained activity were determined during the growth cycle of Micrococcus MCCB 104. The culture was inoculated to an absorbance $(A)$ of 0.01 at $600 \mathrm{~nm}$ (approx. $10^{3} \mathrm{CFU} \mathrm{ml}^{-1}$ ) in $500 \mathrm{ml}$ of ZoBell's broth ( $\mathrm{pH} \mathrm{7.0)}$ and incubated on a magnetic stirrer at room temperature (approx. $28^{\circ} \mathrm{C}$ ). Starting at hour zero and then at periodic intervals, aliquots of $2 \mathrm{ml}$ culture were drawn aseptically; $1 \mathrm{ml}$ was used for monitoring growth $\left(A_{600 \mathrm{~nm}}\right)$ and $1 \mathrm{ml}$ centrifuged at $10000 \times g$ at $4^{\circ} \mathrm{C}$ for $10 \mathrm{~min}$ to pellet the cells. The supernatant was filtersterilised, as mentioned above, and antagonistic activity was tested against Vibrio alginolyticus MCCB 112, in triplicate, as mentioned earlier. The plates were incubated at $28^{\circ} \mathrm{C}$ for $24 \mathrm{~h}$ and observed for zones of clearing around the discs. This was continued until the culture entered the decline phase. Antagonistic activity was quantitatively expressed in terms of the diameter $(\mathrm{mm})$ of the zone of inhibition around the discs.

Co-culture experiments. Micrococcus MCCB 104 and Vibrio alginolyticus MCCB 112 were precultured separately in ZoBell's broth at $28^{\circ} \mathrm{C}$ on a shaker (100 rpm) overnight. $V$. alginolyticus was then inoculated into $100 \mathrm{ml}$ of ZoBell's broth in conical flasks (250 ml volume) to provide an initial cell density of about $10^{3} \mathrm{CFU} \mathrm{ml}{ }^{-1}$, whereas the initial levels of Micrococcus MCCB 104 were $10^{5}, 10^{6}, 10^{7}$ and $10^{8} \mathrm{CFU} \mathrm{ml}^{-1}$, respectively. All combinations were in duplicate. The flasks were incubated at $28^{\circ} \mathrm{C}$ on a shaker (100 rpm), and samples $(1 \mathrm{ml})$ were withdrawn daily for $V$. alginolyticus counts. The cell count was taken by spread plating $0.2 \mathrm{ml}$ aliquots of serially diluted broth suspensions on plates of thiosulphate citrate bile salts sucrose (TCBS) agar (HiMedia). The plates were incubated at $28^{\circ} \mathrm{C}$ for $2 \mathrm{~d}$, and colonies were counted and expressed as CFU of $V$. alginolyticus in the coculture. This proce- dure was specifically chosen because Micrococcus MCCB 104 failed to grow on TCBS agar plates.

Preliminary characterisation of the antagonistic substance. The extracellular product having the antagonistic property was evaluated for the presence of bacteriocin, lipid, carbohydrate, hydrogen peroxide, acid and alkali by the disc diffusion method, as described earlier. To examine the presence of bacteriocin, the culture supernatant of Micrococcus MCCB 104, filtered through a $0.2 \mu \mathrm{m}$ pore-size cellulose-acetate membrane filter (Sartorius) and neutralised to $\mathrm{pH} 7.0$, was incubated at $37^{\circ} \mathrm{C}$ for $1 \mathrm{~h}$ with the proteolytic enzymes Proteinase $\mathrm{K}\left(1 \mathrm{mg} \mathrm{ml}^{-1}\right)$, pronase E $(2 \mathrm{mg}$ $\left.\mathrm{ml}^{-1}\right), \alpha$ chymotrypsin $\left(5 \mathrm{mg} \mathrm{ml}^{-1}\right)$, trypsin (50 $\mathrm{mg} \mathrm{ml}^{-1}$ ) and lysozyme (1 $\mathrm{mg} \mathrm{ml}^{-1}$ ). For lipids and carbohydrates, the cell-free supernatant was treated with lipase $\left(1 \mathrm{mg} \mathrm{ml}^{-1}\right)$ and $\alpha$-amylase $\left(1 \mathrm{mg} \mathrm{ml}^{-1}\right)$; for hydrogen peroxide, the cell-free supernatant was treated with catalase $\left(2 \mathrm{mg} \mathrm{ml}^{-1}\right)$. All the enzymes were procured from Sigma-Aldrich. To examine alkali and acid production, the supernatant was neutralised to $\mathrm{pH} 7.0$ by the addition of $1 \mathrm{~N} \mathrm{HCl}$ or $1 \mathrm{~N} \mathrm{NaOH}$ (Qualigens). Heat sensitivity of the inhibitory substance was tested by heating the cell-free supernatant in a water bath for $30 \mathrm{~min}$ at 60 and $80^{\circ} \mathrm{C}$, and autoclaving for $15 \mathrm{~min}$ at $121^{\circ} \mathrm{C}$. Each treated and untreated supernatant was tested for activity against Vibrio alginolyticus MCCB 112, and the presence of an inhibitory zone around the discs was determined after incubation for $24 \mathrm{~h}$ at $28^{\circ} \mathrm{C}$.

Influence of growth conditions on the production of antagonistic substance. The influence of $\mathrm{pH}$, temperature and $\mathrm{NaCl}$ concentration on production of the antagonistic substance by the Micrococcus MCCB 104 was studied. Sterilised nutrient broth supplemented with $1.5 \% \mathrm{NaCl}$ (pH adjusted to 4.0, 5.0, 6.0, 7.0, 8.0, $9.0,10.0$, or 11.0) was inoculated with $0.1 \mathrm{ml}$ of an overnight culture of Micrococcus MCCB 104 and incubated at $28^{\circ} \mathrm{C}$ for $24 \mathrm{~h}$. Similarly, nutrient broth ( $\mathrm{pH} 7.0$, $\mathrm{NaCl} 1.5 \%$ ) was inoculated, as described above, and incubated at $4,15,20,25,30,35,40$, or $45^{\circ} \mathrm{C}$ for $24 \mathrm{~h}$. The influence of different concentrations of sodium chloride was assessed by observing growth at $28^{\circ} \mathrm{C}$ in $1 \%$ tryptone broth ( $\mathrm{pH} 7.0 ;$ HiMedia, India) containing $0,0.5,1.0,1.5,2.0,2.5,3.0$, or $3.5 \% \mathrm{NaCl}$. A cell-free supernatant was obtained by centrifugation followed by filtration, as described earlier, to assess the inhibitory activity by the disc diffusion method on Vibrio alginolyticus MCCB 112.

Pathogenicity of Micrococcus MCCB 104 to Macrobrachium rosenbergii larvae. Pathogenicity of Micrococcus MCCB 104 was assessed on larvae of Macrobrachium rosenbergii (Stage PL1) brought from a commercial hatchery in Kerala. They were maintained for $3 \mathrm{~d}$ in $10 \mathrm{ppt}$ seawater and were fed with sterile lab- 
oratory-made egg custard. Apparently healthy larvae were then distributed, 50 each, to $15 \mathrm{l}$ fibreglass tanks containing $10 \mathrm{l}$ of $10 \mathrm{ppt}$, autoclaved seawater. Micrococcus MCCB 104 culture grown for $24 \mathrm{~h}$ was scraped from the surface of ZoBell's agar plates into sterile saline and centrifuged at $3000 \times g$ for $10 \mathrm{~min}$. The pellet was resuspended in fresh saline and adjusted to an $A_{600 \mathrm{~nm}}$ value of 1.0 (corresponding to $10^{9} \mathrm{CFU} \mathrm{ml}{ }^{-1}$ ). The above suspension was added to the larval rearing water to give a final cell count of $10^{8} \mathrm{CFU} \mathrm{ml} \mathrm{m}^{-1}$. The control tank did not have any bacterial inoculum supplemented. The above experiment was done in triplicate. Larvae were monitored for $4 \mathrm{~d}$ and observed for mortality.

\section{RESULTS}

The bacterium MCCB 104 is Gram-positive and forms yellow pigmented colonies of non-motile cocci on ZoBell's agar with the ability to grow at $\mathrm{pH} 6.0$, $37^{\circ} \mathrm{C}$ and in $7.5 \% \mathrm{NaCl}$. It is glucose non-fermentative, produces glucose acid, mannose acid, oxidase and catalase, but not arginine dihydrolase. MCCB 104 reacts positive to the nitrate reduction test and citrate utilisation test and negative to the indole test; it is able to utilise D-mannose, D-xylose, D-mannitol, sucrose, arabinose, raffinose, but not meso-inositol, D-trehalose, adonitol, D-cellobiose and galactose as sole carbon sources. It was resistant to antibiotic furazolidone and sensitive to novobiocin, bacitracin, ampicillin, streptomycin, rifampicin, neomycin, erythromycin, kanamycin, chloramphenicol, ciprofloxacin, oxytetracycline, nitrofurantoin and the vibriostatic compound O/129. It can hydrolyse gelatine, starch and cellulose, but not tributyrin and chitin. The above characteristics equate Culture No. MCCB 104 to the genus Micrococcus (Buchanan \& Gibbons 1974). Accurate taxonomical
Table 2. Micrococcus MCCB 104. Effect of $\mathrm{pH}$, temperature and salt $(\mathrm{NaCl})$ concentration on growth (+: visible growth; ++: moderate growth $_{i}+++$ : excellent growth ${ }_{i}-$ : no growth) and size of inhibition zone

\begin{tabular}{|lcc|}
\hline Parameter & Growth & $\begin{array}{c}\text { Zone of inhibition }(\mathrm{mm}) \\
\text { at } 24 \mathrm{~h}\end{array}$ \\
\hline $\mathbf{p H}$ & & \\
4,5 & & 0 \\
6 & - & 13 \\
$7,8,9$ & + & 15 \\
10,11 & +++ & 10 \\
Temperature of incubation $\left({ }^{\circ} \mathbf{C}\right)$ & \\
4 & - & 0 \\
15 & + & 0 \\
20 & + & 12 \\
25 & ++ & 14 \\
30 & ++ & 14 \\
35 & +++ & 16 \\
40 & +++ & 16 \\
45 & - & 0 \\
Salt concentration $(\%)$ & \\
0 & + & 12 \\
$0.5,1.0,1.5$ & +++ & 16 \\
2.0 & ++ & 14 \\
$2.5,3.0$ & ++ & 14 \\
3.5 & + & 0 \\
& & \\
& & ++
\end{tabular}

positioning awaits results of $16 \mathrm{~S}$ ribosomal DNA sequencing.

An antagonism assay by disc diffusion showed that Micrococcus MCCB 104 inhibited Vibrio and Aeromonas isolates (Table 1), with clearing zones of 15 to $20 \mathrm{~mm}$ diameter. However, yeasts, actinomycetes, Bacillus and Pseudomonas isolates, along with 2 isolates of $V$. splendidus II were resistant. An antagonism assay conducted with cell-free culture supernatant of Micrococcus MCCB 104 revealed similar inhibitory activity.

The antagonistic substance produced by Micrococcus MCCB 104 was detectable by disc diffusion assay in batch culture from $12 \mathrm{~h}$ of growth onwards. Growth was in stationary phase by $42 \mathrm{~h}$ and declined at about $48 \mathrm{~h}$ of post-inoculation. Production of the antagonistic substance peaked at the stationary phase, and maximum antagonistic activity was observed at $42 \mathrm{~h}$ of growth (Fig. 1).

In co-culture, growth of Vibrio alginolyticus MCCB 112 was inhibited by Micrococcus MCCB 104 when inoculated at an initial level of $10^{5}$ to $10^{7} \mathrm{CFU} \mathrm{m}{ }^{-1}$ (Fig. 2). All counts of the strain MCCB 104 in the co-culture
Fig. 1. Micrococcus MCCB 104. Growth and antagonistic activity against Vibrio alginolyticus MCCB 112. OD: optical density 
Table 3. Macrobrachium rosenbergii. Pathogenicity test of Micrococcus MCCB 104 on larvae (PL1) (n=3)

\begin{tabular}{|lcccc|}
\hline \multirow{2}{*}{$\begin{array}{l}\text { Treatment groups } \\
\end{array}$} & \multicolumn{5}{c}{$\begin{array}{c}\text { Number of larvae that survived } \\
\text { (of 50) }\end{array}$} \\
& $24 \mathrm{~h}$ & $48 \mathrm{~h}$ & $72 \mathrm{~h}$ & $96 \mathrm{~h}$ \\
\hline $\begin{array}{l}\text { Micrococcus MCCB 104 } \\
\left(1.6 \times 10^{8} \mathrm{CFU} \mathrm{ml}^{-1}\right)\end{array}$ & $48 \pm 1$ & $45 \pm 1$ & $44 \pm 1$ & $41 \pm 2$ \\
Control & $46 \pm 2$ & $44 \pm 3$ & $41 \pm 2$ & $36 \pm 6$ \\
\hline
\end{tabular}

allowed initial growth of $V$. alginolyticus, but it never attained the cell count of the control. Flasks inoculated with the highest count $\left(10^{7} \mathrm{CFU} \mathrm{ml}{ }^{-1}\right)$ of Micrococcus MCCB 104 showed the lowest count of $V$. alginolyticus (approx. $10^{4} \mathrm{CFU} \mathrm{ml}^{-1}$ ).

The activity of the cell-free culture supernatant remained relatively stable after the treatments with $\alpha$-chymotrypsin, trypsin, Proteinase K, pronase E, lysozyme, lipase, catalase and $\alpha$-amylase, as the zones of inhibition $(16 \mathrm{~mm})$ obtained were similar to that of control (untreated cell-free culture supernatant). Similar antagonistic activity was observed when the cell-free culture supernatant was neutralised to $\mathrm{pH}$ 7.0. There was no loss of antagonistic activity even when supernatants were autoclaved at $121^{\circ} \mathrm{C}$ for $15 \mathrm{~min}$, indicating extreme heat stability of the substance.

$\mathrm{pH} 7.0,8.0$ and 9.0 were found to be the optima with a corresponding zone of inhibition of $15 \mathrm{~mm}$ diameter (Table 2). There was no growth at $\leq \mathrm{pH}$ 5.0. Growth was maximum at 35 and $40^{\circ} \mathrm{C}$, with a $16 \mathrm{~mm}$ diameter zone of inhibition. There was no growth at 4 or $45^{\circ} \mathrm{C}$. Maximum growth was observed in the medium containing $0.5,1$ and $1.5 \% \mathrm{NaCl}$, with a $16 \mathrm{~mm}$ diameter zone of inhibition, and minimal at 3 and $3.5 \% \mathrm{NaCl}$, with no antagonistic activity.

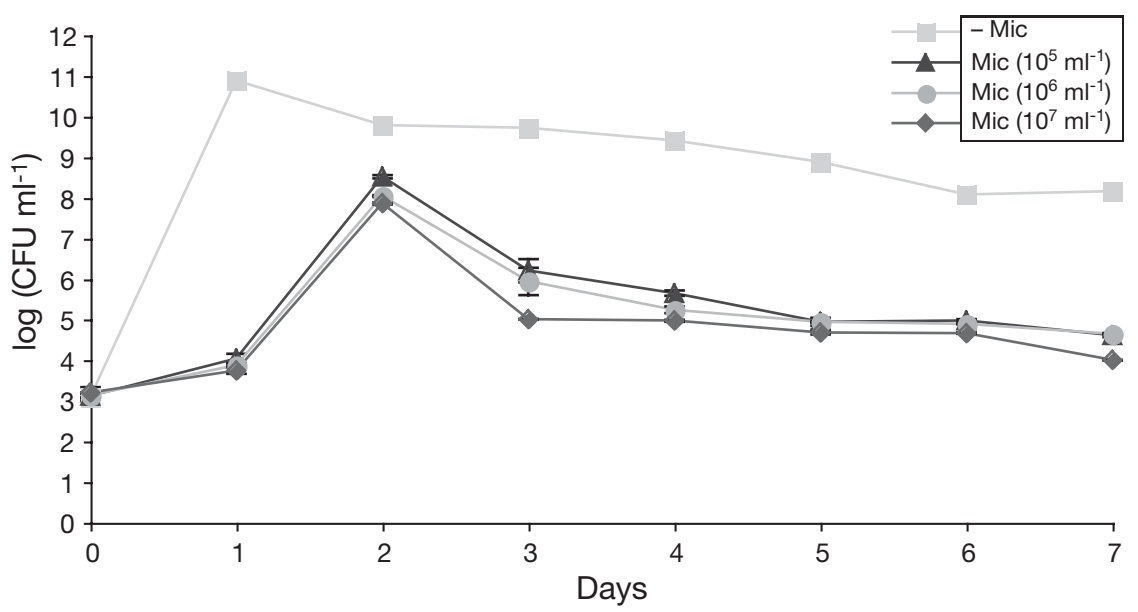

Fig. 2. Vibrio alginolyticus MCCB 112 . Growth at $28^{\circ} \mathrm{C}$ in ZoBell's broth (15 ppt) with and without Micrococcus MCCB 104 (Mic) at different initial cell densities. Error bars are mean \pm SE
Survival of Macrobrachium rosenbergii post-larvae was not affected by the challenge of Micrococcus MCCB 104 in larval rearing water (Table 3).

\section{DISCUSSION}

Micrococcus spp. are typical components of the heterotrophic bacterial microflora of various environments and have been recovered from soil (Rahman et al. 2002), seawater (Tanaka et al. 2001), marine sediments (Zhong et al. 2002) and prawn-rearing water (Phatarpekar et al. 2002). The Micrococcus MCCB 104 isolated in the present study from hatchery seawater inhibited several of the pathogenic isolates of Vibrio and Aeromonas spp. tested here. Results of the antagonism assay using the disc diffusion method with cellfree culture supernatant of Micrococcus MCCB 104 suggest that an extracellular product is likely to be responsible for the observed antagonism. Strains of Micrococcus spp. have been generally used as starter cultures in fermented beef and pork sausages (Bacus 1984) as these can prevent the growth of pathogenicmicroorganisms by organic acid production (Schillinger \& Lucke 1990). Irianto \& Austin (2002a) reported that an isolate of unidentified Gram-positive cocci had potential in combating A. salmonicida infections in rainbow trout Oncorhynchus mykiss (Walbaum). It is noteworthy that many of the Vibrio species tested here are reported pathogens in aquaculture systems (Sindermann 1990, Austin \& Austin 1993).

Co-culture experiments showed that the isolate Micrococcus MCCB 104 inhibited the growth of Vibrio alginolyticus when the initial count of the antagonist was 100 to 1000 times greater than that of the prawn pathogen. This indicates that the antagonist must be present at significantly higher levels than the pathogen, and the degree of inhibition increases with increased levels of the antagonist. Therefore, as a potential antagonistic probiotic, Micrococcus MCCB 104 has to be supplied in sufficient quantity and on a regular basis into the system.

Pridmore et al. (1996) reported that variacin, a bacteriocin produced by Micrococcus varians, inhibited other Gram-positive bacteria, but not Gramnegative bacteria. El-Shafei (1997) observed that the introduction of Micrococcus to fungal cultures resulted in lysis and inhibition of fungal growth, and attributed this to the pro- 
duction of mycolytic enzymes. Preliminary characterisation of the antagonistic substance in the cell-free culture supernatant of Micrococcus MCCB 104 suggested that it was a non-proteinaceous compound. Moreover, the compound was found to be highly heat-stable and survived autoclaving. This thermostability should prove to be of greater use if the compound is incorporated into feed, where exposure to high temperature is unavoidable. At present, work is in progress to purify and further characterise the antagonistic substance from the culture supernatant.

The maximum production of antagonistic substance was observed at pH 7.0 to 9.0 and at temperatures of 35 to $40^{\circ} \mathrm{C}$, which was also the optimum $\mathrm{pH}$ and temperature for the growth of the organism. This suggests a close relation between growth of Micrococcus MCCB 104 and the production of the antagonistic substance. This was further confirmed by the results in Table 2, which show that production of the antagonistic substance was maximum at $\mathrm{NaCl}$ concentrations between 0.5 and $1.5 \%$, which was also optimal for growth of the organism.

One of the most important criteria for considering a bacterium as a candidate to be used in biocontrol programs in any culture system is its non-pathogenicity (Verschuere et al. 2000). This study has clearly shown that Micrococcus MCCB 104 is a non-pathogen to prawn larvae, even at $10^{8} \mathrm{CFU} \mathrm{ml}^{-1}$. Moreover, Micrococcus species have not been recognised and reported elsewhere as prawn pathogens. The present work strengthens the candidature of Micrococcus MCCB 104 as an 'antagonistic probiotic' in prawn larval rearing systems.

To our knowledge, this is the first report of an isolate of Micrococcus with properties antagonistic to vibrios associated with prawn larval rearing systems, although its identity is tentative and awaits DNA sequencing results. In this research it has been demonstrated that Micrococcus MCCB 104 can suppress vibrios in vitro. The nature of the antagonistic substance remains to be established; further work is underway in this regard. In conclusion, the study indicates the possibility of developing a biological method of suppressing or excluding vibrios associated with prawn larval rearing systems using Micrococcus MCCB 104.

Acknowledgements. This study was carried out as part of a project supported by the Department of Science and Technology (Project Code: SP/SO/C-40/99), Government of India. The first author is grateful to the Department of Science and Technology, Government of India, for providing a fellowship during the study. We thank Prof. R. H. Reed from the Division of Biomedical Sciences, Northumbria University, Newcastle Upon Tyne, UK, for reviewing the language in the manuscript.

\section{LITERATURE CITED}

Austin B, Allen DA (1982) Microbiology of laboratory-hatched brine shrimp (Artemia). Aquaculture 26:369-383

Austin B, Austin DA (1993) Disease in farmed and wild fish. Aeromonadaceae representatives (Aeromonas salmonicida) in bacterial fish pathogens, 2nd edn. Ellis Horwood, Chichester

Austin B, Billaud AC (1990) Inhibition of the fish pathogen, Serratia liquefaciens, by an antibiotic-producing isolate of Planococcus recovered from seawater. J Fish Dis 13: $553-556$

Austin B, Stuckey LF, Robertson PAW, Effendi I, Griffith DRW (1995) A probiotic strain of Vibrio alginolyticus effective in reducing diseases caused by Aeromonas salmonicida, Vibrio anguillarum and Vibrio ordalii. J Fish Dis 18:93-96

Bacus JN (1984) Utilization of microorganisms in meat processing. John Wiley \& Sons, New York

Baticados MCL, Cruz-Lacierda ER, dela Cruz MC, Duremdez-Fernandez RC, Gacutan RQ, Lavilla-Pitogo CR, Lio-Po GD (1990) Diseases of penaeid shrimps in the Philippines. Aquaculture Department, SEAFDEC, Tigbauan, Iloilo, p 46

Buchanan RE, Gibbons NE (1974) Bergey's manual of determinative bacteriology. The Williams and Wilkins Company, Baltimore, MD

Chythanya R, Karunasagar I, Karunasagar I (2002) Inhibition of shrimp pathogenic vibrios by a marine Pseudomonas I2 strain. Aquaculture 208(1-2):1-10

El-Shafei HA (1997) Influence of L-sorbose and the cell-walllytic Micrococcus sp. on the major polymers of Aspergillus fumigatus. Polym Degrad Stabil 57:151-156

Gatesoupe FJ (1994) Lactic acid bacteria increase the resistance of turbot larvae, Scophthalmus maximus, against pathogenic Vibrio. Aquat Living Resour 7:277-282

Gomez-Gil B (1995) The use of bacteria as probionts in shrimp larviculture. In: Lavens P, Jaspers E, Roelants I (eds) Larvi'95-Fish and shellfish larviculture symposium. Special Publication Vol. 24, European Aquaculture Society, Ghent, p 479

Gomez-Gil B, Roque A, Turnbull JF (2000) The use and selection of probiotic bacteria for use in the culture of larval aquatic organisms. Aquaculture 191:259-270

Hameed ASS, Rahaman KH, Alagan A, Yoganandhan K (2003) Antibiotic resistance in bacteria isolated from hatchery-reared larvae and post-larvae of Macrobrachium rosenbergii. Aquaculture 217:39-48

Irianto A, Austin B (2002a) Use of probiotics to control furunculosis in rainbow trout, Oncorhynchus mykiss (Walbaum). J Fish Dis 25:333-342

Irianto A, Austin B (2002b) Probiotics in aquaculture. J Fish Dis 25:633-642

Lalitha KV, Surendran PK (2004) Bacterial microflora associated with farmed freshwater prawn Macrobrachium rosenbergii (de Man) and the aquaculture environment. Aquacult Res 35(7):629

Lightner DV (ed) (1996) A handbook of shrimp pathology and diagnostic procedures for disease of cultured penaeid shrimp. World Aquaculture Society, Baton Rouge, LA

New MB (1995) Status of freshwater prawn farming: a review. Aquacult Res 26:1-54

Phatarpekar PV, Kenkre VD, Sreepada RA, Desai UM, Achuthankutty CT (2002) Bacterial flora associated with larval rearing of the giant freshwater prawn, Macrobrachium rosenbergii. Aquaculture 203:279-291

Pridmore D, Rekhif N, Pittet AC, Suri B, Mollet B (1996) 
Variacin, a new lanthionine-containing bacteriocin produced by Micrococcus varians: comparison to lactacin 481 of Lactococcus lactis. Appl Environ Microbiol 62(5): 1799-1802

Prieto A, Garcia T, Rodriguez C (1987) Microorganismos presentes en quistes de Artemia salina y su sensibilidad 'in vitro' a tres desinfectantes. 1. Bacterias Gram positivas. Bol Tec Acuicult 23:1-11

Rahman KSM, Thahira-Rahman J, Lakshmanaperumalsamy P, Banat IM (2002) Towards efficient crude oil degradation by a mixed bacterial consortium. Bioresour Technol 85: $257-261$

Rengpipat S, Rukpratanporn S, Piyatiratitivorakul S, Menasaveta P (2000) Immunity enhancement in black tiger shrimp (Penaeus monodon) by a probiont bacterium (Bacillus S11). Aquaculture 191:271-288

Robertson PAW, O'Dowd C, Burrells C, Williams P, Austin B (2000) Use of Carnobacterium sp. as a probiotic for Atlantic salmon (Salmo salar L.) and rainbow trout (Oncorhynchus mykiss, Walbaum). Aquaculture 185: 235-243

Schillinger U, Lücke FK (1990) Possible use of bacteriocinproducing lactobacilli in meats. FEMS Microbiol Rev Spec Issue 97:85

Sindermann CJ (1990) Principal diseases of marine fish and shellfish, Vol 2, 2nd edn. Academic Press, New York

Singh ISB (1990) Bacterial flora of larvae and larval rearing system of the giant fresh water prawn Macrobrachium rosenbergii. In: Nair NB (ed) Proc 2nd Kerala Science Congress, 23-25 February, 1990, Thiruvananthapuram.

Editorial responsibility: Timothy Flegel,

Bangkok, Thailand
State Committee on Science, Technology \& Environment, Govt of Kerala, Thiruvananthapuram, p 190-194

Sugita H, Matsuo N, Hirose Y, Iwato M, Deguchi Y (1997) Vibrio sp. strain NM10, isolated from the intestine of a Japanese coastal fish, has an inhibitory effect against Pasteurella piscida. Appl Environ Microbiol 63:4986-4989

Sung HH, Hsu SF, Chen CK, Ting YY, Chao WL (1999) Relationships between disease outbreak in cultured tiger shrimp (Penaeus monodon) and the composition of Vibrio communities in pond water and shrimp hepatopancreas during cultivation. Aquaculture 192:101-111

Tanaka T, Burgess JG, Wright PC (2001) High-pressure adaptation by salt stress in a moderately halophilic bacterium obtained from open seawater. Appl Microbiol Biotechnol 57:200-204

Vandenbergh P (1993) Lactic acid bacteria, their metabolic products and interference with microbial growth. FEMS Microbiol Rev 12:221-238

Verschuere L, Rombaut G, Sorgeloos P, Verstraete W (2000) Probiotic bacteria as biological control agents in aquaculture. Microbiol Mol Biol Rev 64:655-671

Weston DP (1996) Environmental considerations in the use of antibacterial drugs in aquaculture. In: Michel CM, Alderman DJ (eds) Aquaculture and water resource management. Office International des Epizooties, Paris

Williams ST, Vickers JC (1986) The ecology of antibiotic production. Microb Ecol 12:43-52

Zhong Z, Caspi R, Mincer T, Helinski D and 6 others (2002) A $50-\mathrm{kb}$ plasmid rich in mobile gene sequences isolated from a marine Micrococcus. Plasmid 47:1-9

Submitted: January 28, 2005; Accepted: June 2, 2005

Proofs received from author(s): December 6, 2005 